\section{MANTIS INDICA MUKHERJEE, 1995: A SYNONYM OF STATILIA NEMORALIS (SAUSSURE, 1870) (INSECTA: MANTODEA)}

\section{Parbati Chatterjee ${ }^{1}$ \& Tushar Kanti Mukherjee ${ }^{2}$}

${ }^{1}$ Department of Zoology, Vidyasagar Evening College, Kolkata, West Bengal 700006, India

${ }^{2} 65 \mathrm{~A} / 6$, Swinhoe Lane, Kolkata, West Bengal 700073, India

${ }^{1}$ uparbati@yahoo.co.in, ${ }^{2}$ mukherjee.tushar@gmail.com (corresponding author)

Taxonomy of mantids based on external features may often lead to a wrong assignment of the status of a new species. Hence emphasis is given on the structure of male genitalia which provides a perfect clue to the status of the species. In this paper a new synonym has been established by comparing external features and genitalia. Mantis indica (Images 5 \& 6, holotype female) was described by Mukherjee in Mukherjee et al. (1995) based on one male and one female from Himachal Pradesh, India. Later, the dissected genitalia of this species were found to match perfectly with the genitalia of Statilia nemoralis (Saussure, 1870). However, some morphological distinctions are obvious between the two species. The three species studied under the genus Mantis were: Mantis religiosa L., 1758, Mantis inornata Werner, 1930, and Mantis indica Mukherjee, 1995. The three species studied under the genus Statilia were: Statilia apicalis (Saussure, 1871), Statilia maculata (Thunberg, 1784) and Statilia nemoralis (Saussure, 1870). All these were studied for their external features. The genitalia were dissected out from species as mentioned in materials and method section. It is to be noted that Roy (1999: 163) mentioned that by description Mantis indica Mukherjee, 1995 falls under the genus Statilia, however, the description of genitalia was not given. Berg et al. (2011: 44) attested the view of Roy (1999).

Materials and Method: The study materials came from West Bengal and Himachal Pradesh of India as mentioned here. These

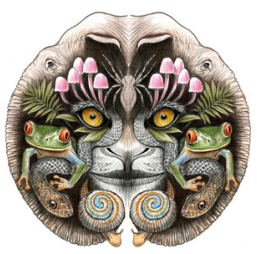

ISSN

Online 0974-7907 Print 0974-7893

\section{OPEN ACCESS} were identified based on external and genitalia characters.

Statilia nemoralis (Saussure, 1870): 25.x.2005, 3 males, Narendrapur, South 24 paraganas, West Bengal, $22.459729^{\circ} \mathrm{N} \& 88.381920^{\circ} \mathrm{E}$, coll. P. Chatterjee; 14.ix.2005, 2 males, Ranaghat, Nadia, West Bengal, $23.172389^{\circ} \mathrm{N} \& 88.568001^{\circ} \mathrm{E}$, coll. P. Chatterjee.

Statilia maculata (Thunberg, 1784), 22.x.1999, 2 males, Purulia, West Bengal, $23.328974^{\circ} \mathrm{N}$ \& $86.370392^{\circ} \mathrm{E}$, coll. P. Chatterjee.

Mantis indica Mukherjee, in Mukherjee et al. 1995: 4.vi.1971, holotype female, Chail, Himachal Pradesh, (NZSI) (figs. 5 \& 6), $30.969722^{\circ} \mathrm{N} \& 77.197499^{\circ} \mathrm{E}$, coll. M. Chandra; 30.xi.1975, allotype male, Renuka Lake, Himachal Pradesh, $30.523151^{\circ} \mathrm{N} \& 77.308044^{\circ} \mathrm{E}$, coll. A. Kumar.

Mantis inornata Werner, 1930: 18.ix.2001, 1 male, Shillong, Meghalaya, $25.583902^{\circ} \mathrm{N} \& 91.877289^{\circ} \mathrm{E}$, coll. NA.

Results and Discussion: In both the species, Mantis religiosa and Mantis inornata, the hypophallus is distinctly very big and oval elongated; its distal end is blunt finger-like in Mantis religiosa (Bazyluk 1960, fig. 51), but more pointed in Mantis inornata (Image 1; also Bazyluk 1960, fig. 52). The hypophallus is broad and triangular in Statilia maculata (Image 2); but this is very narrowly triangular in both Mantis indica (Image 3) and

DOI: http://dx.doi.org/10.11609/JoTT.03289.4907-9 | ZooBank: urn:Isid:zoobank.org:pub:41255A6C-F487-4B22-81E3-E93A4DC986E9

Editor: Martin B.D. Stiewe, The Natural History Museum, UK.

Date of publication: 26 October 2013 (online \& print)

Manuscript details: Ms \# 03289 | Received 05 August 2012 | Final received 30 July 2013 | Finally accepted 22 September 2013

Citation: Chatterjee, P. \& T.K. Mukherjee (2013). Mantis indica Mukherjee, 1995: a synonym of Statilia nemoralis (Saussure, 1870) (Insecta: Mantodea). Journal of Threatened Taxa 5(14): 4907-4909; http://dx.doi.org/10.11609/JoTT.o3289.4907-9

Copyright: (c) Chatterjee \& Mukherjee 2013. Creative Commons Attribution 3.0 Unported License. JoTT allows unrestricted use of this article in any medium, reproduction and distribution by providing adequate credit to the authors and the source of publication.

Funding: None.

Competing Interest: Authors declare no competing interests.

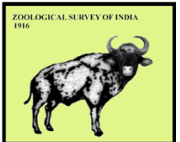

Acknowledgements: The authors wish to express their sincere gratitude to the Director, Zoological Survey of India for encouragement and laboratory facilities. The authors are also indebted to the anonymous referee for valuable guidance. 


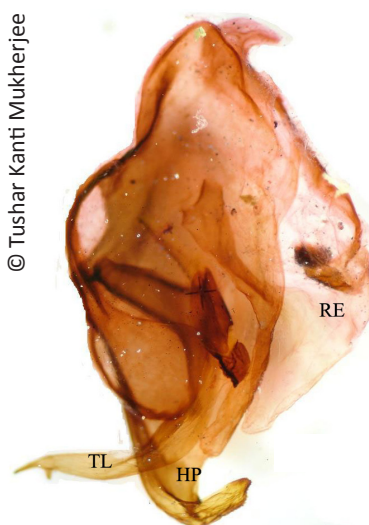

Image 1. Mantis inornata genitalia

HP - Hypophallus; RE - Right epiphallus; TL - Titillator

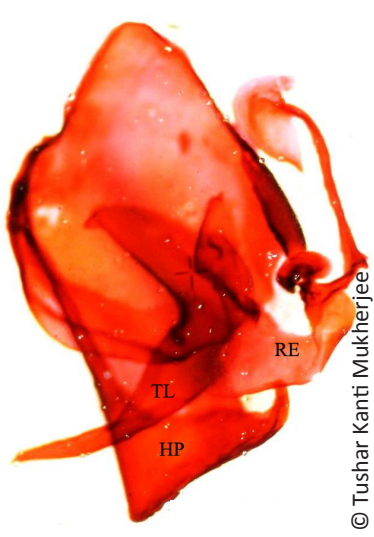

Image 2. Statilia maculata genitalia

HP - Hypophallus; RE - Right epiphallus; TL - Titillator

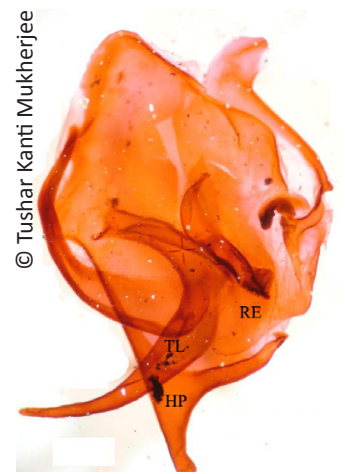

Image 3. Mantis indica genitalia

HP - Hypophallus; RE - Right epiphallus; TL - Titillator

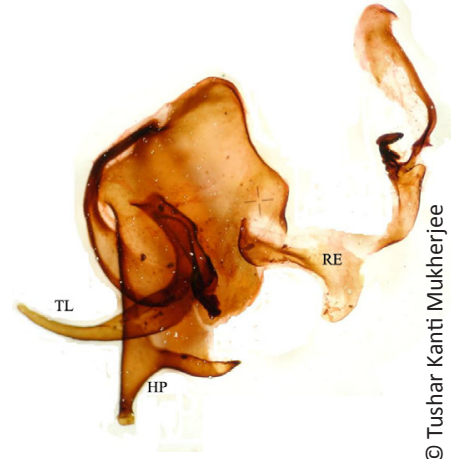

Image 4. Statilia nemoralis genitalia HP - Hypophallus; RE - Right epiphallus; TL - Titillator

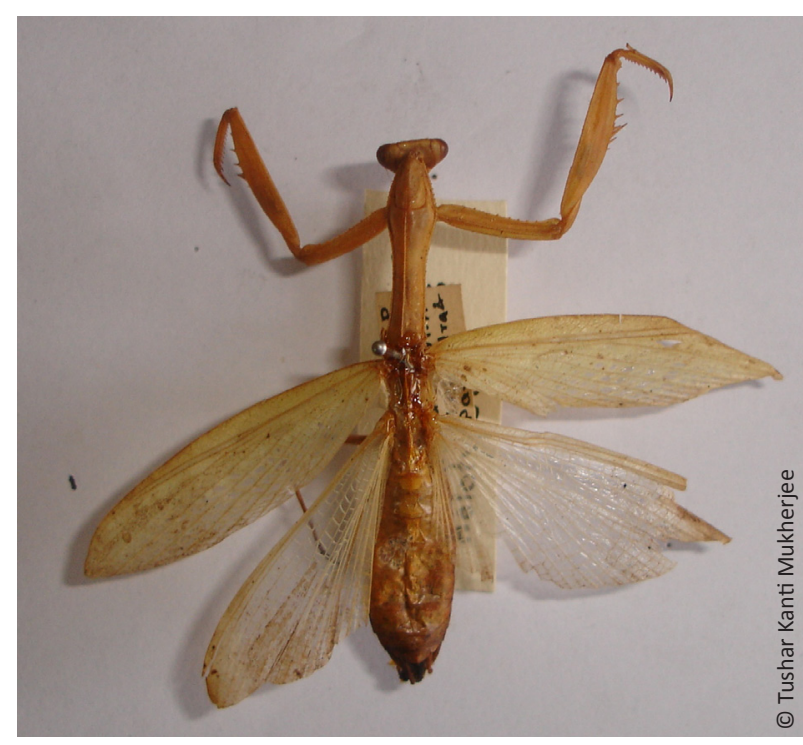

Image 5. Mantis indica (holotype female), dorsal view

Statilia nemoralis (Image 4). The apex of the titillator of Mantis religiosa and Mantis inornata are distinct by its bifid apex. This feature is absent in Mantis indica, Statilia nemoralis and Statilia maculata.

The development of contiguous internal apical lobes of coxae puts Mantis indica under the genus Statilia. This is supported by the presence of (i) black patch on femur, (ii) pale yellow claw groove, and (iii) black internal spines with extensions. However, there are some morphological similarities between Mantis indica and Mantis inornata (Table 1) whose genitalia are distinctly different. Again, Mantis indica and Mantis inornata deviated much from Mantis religiosa; some characters common to these two species are quite diagnostic in members of Statilia.

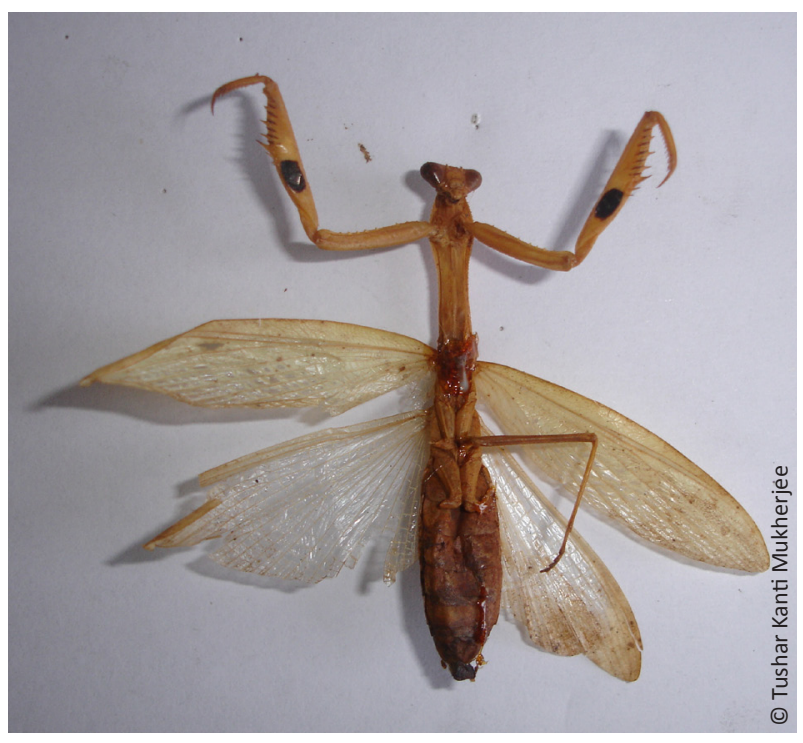

Image 6. Mantis indica (holotype female), ventral view

Some of the specific characters of Mantis religiosa are not seen in any species of the two genera which may be assumed as a separate line of evolution (Table 1).

Thus the following inferences may be made on the two genera:

1. Mantis religiosa has probably deviated more from the main stock of the genus Mantis.

2. Mantis inornata seems to be more primitive by the development of no patches on coxa, more triangularly elongated hypophallus and pale yellow claw groove.

3. Mantis indica and Statilia nemoralis share most characters but the position of the claw groove is different in the two species. These two species seem to represent an intermediate stage between the advanced forms 
Table 1. Morphological differences among related species of Mantis and Statilia

\begin{tabular}{|l|l|l|l|l|l|}
\hline Species & Position of claw groove & $\begin{array}{l}\text { Internal apical } \\
\text { lobe of fore coxa }\end{array}$ & Color of coxal area & $\begin{array}{l}\text { Prosternal basal } \\
\text { patch }\end{array}$ & Inner patch of femur \\
\hline M. religiosa & Medial & Divergent & $\begin{array}{l}\text { Yellow spot } \\
\text { enclosed by black }\end{array}$ & Not black & Yellow \\
\hline M. inornata & Medial & Divergent & Not black & Not black & Pale yellow \\
\hline M. indica & Medial & Contiguous & Not black & Not black & Pale white + Black \\
\hline S. maculata & In front of middle & Contiguous & Black & Black & Yellow \\
\hline S. apicalis & In front of middle & Contiguous & Not black & Black & Yellow \\
\hline S. nemoralis & In front of middle & Contiguous & Not black & Not black & Yellow + Black \\
\hline
\end{tabular}

(Mantis religiosa and Mantis inornata) and the species under the genus Statilia apicalis and Statilia maculata).

4. The important characters for consideration of phylogeny are: contiguous/divergent internal apical lobes of coxa, position of claw groove, shape and form of hypophallus and titillator.

\section{REFERENCES}

Bazyluk, W. (1960). Die geographische Verbreitung und Variabilität von Mantis religiosa (L.) (Mantodea, Mantidae), sowie Beschreibungen neuer Unterarten. Annales Zoologici Fennici 16(15): 231-270. Warschau.

Berg, M.K., C.J. Schwarz \& J.E. Mehl (2011). Die Gottesanbeterin Mantis Religiosa. Series: Invertebrates, 521pp.
Linnaeus, C. (1758). Systema Naturae. Holmiae, laur. Salvius, 10:426. Stockholm.

Mukherjee, T.K., A.K. Hazra \& A.K. Ghosh (1995). The Mantid fauna of India (Insecta : Mantodea). Oriental Insects 29(1): 185-358; http:// dx.doi.org/10.1080/00305316.1995.10433744

Roy, R. (1999). Une Nouvelle Espèce Africaine Du Genre Mantis Linné [Dictyoptera, Mantodea, Mantidae]. Revue francaise d'Entomologie (N.S.) 21(4): 163-166

Saussure, H. de (1870). Additions au Systeme des Mantides. Mitteilungen der Schweizerischen Entomologischen Gesellschaft 3(5): 229.

Saussure, H. de (1871). Mélanges Orthoptérologiques - IV. Mantides. Mémoires de la Société de Physique et d'Histoire Naturelle de Genève, suppl. 21(2):291.

Thunberg, C.P. (1784). Novae Insectorum species. Dissertationes Entomologicae. Novae Insectorum species 3: 61. Upsaliae.

Werner, F. (1930). Indian mantis or praying insects. Proceedings of the Zoological Society of London 1930: 689. 